\title{
SURFACE ROUGHNESS EVOLUTION OF SOILS CONTAINING ROCK FRAGMENTS
}

\author{
BAS VAN WESEMAEL, JEAN POESEN* \\ Laboratory for Experimental Geomorphology, K.U. Leuven, Redingenstraat 16 bis, 3000 Leuven, Belgium \\ TOMÁS DE FIGUEIREDO \\ Escola Superior Agrária de Bragança, Apartado 172, 5300 Braganfa, Portugal \\ AND \\ GERARD GOVERS* \\ Laboratory for Experimental Geomorphology, K.U. Leuven, Redingenstraat 16 bis, 3000 Leuven, Belgium
}

Received 3 May 1994

Accepted 3 February 1995

\begin{abstract}
Soil surface roughness is a dynamic property which determines, to a large extent, erosion and infiltration rates. Although soils containing rock fragments are widespread in the Mediterranean region, the effect of the latter on surface roughness evolution is yet poorly understood. Therefore, laboratory experiments were conducted in order to investigate the effect of rock fragment content, rock fragment size and initial moisture content of the fine earth on the evolution of interrill surface roughness during simulated rainfall. Surface elevations of simulated plough layers along transects of $50 \mathrm{~cm}$ length were measured before and after simulated rainfall (totalling $192.5 \mathrm{~mm}, I=70 \mathrm{~mm} \mathrm{~h}^{-1}$ ) with a laser microreliefmeter. The results were used to investigate whether systematic variations in interrill surface roughness along stony hillslopes in southeastern Spain could be attributed to rock fragment cover and rock fragment size. Soil surface elevations were measured along the contour lines $(50 \mathrm{~cm}$ long transects) with a contact microreliefmeter. Roughness was expressed by two parameters related to the height and frequency of roughness elements, respectively: standard deviation of de-trended surface elevations (random roughness: $R R$ ), and correlation length $(L)$ derived from exponential fits of the autocorrelation functions.

The frequently used assumption that surface roughness $(R R)$ of cultivated topsoils decreases exponentially with cumulative rain is not valid for soil surfaces covered by rock fragments. The $R R$ of soils containing small rock fragments $(1 \cdot 7-$ $2.7 \mathrm{~cm}$ ) increased with cumulative rainfall after an initial decrease during the first $17.5 \mathrm{~mm}$ of rainfall. For soils containing large rock fragments $(7.7 \mathrm{~cm}), R R$ increased with rainfall above a threshold rock fragment content by mass of 52 per cent. For a given rainfall application, $R R$ increased non-linearly with rock fragment content. The correlation length for soils containing small rock fragments decreases with rock fragment content and is significantly lower than for soils with large rock fragments. Soils covered with small rock fragments (large $R R$ and small $L$ ) are thus well protected against raindrop impact by a water film in the depressions between the rock fragments.

On abandoned agricultural fields along hillslopes in southeastern Spain, rock fragments cover increases non-linearly with slope owing to selective erosion of finer particles on steep slopes. The increase of surface cover by large rock fragments $(>25 \mathrm{~mm}$ ) is even more pronounced. The simultaneous increase of rock fragment cover and rock fragment size with slope explains the non-linear increase of $R R$ with slope. These relationships differ for soils covered by platy misaschists and those covered with cubic andesites. The variations in correlation length along the hillslopes are not clear, probably owing to a simultaneous increase in rock fragment cover and rock fragment size. These findings may provide a better prediction of soil surface roughness of interrill areas covered by rock fragments using slope angle and lithology.
\end{abstract}

KEY WORDS soil surface roughness; rock fragment properties; simulated rainfall; semi-arid hillslopes

* National Fund for Scientific Research, Belgium

CCC 0197-9337/96/050399-13

(C) 1996 by John Wiley \& Sons, Ltd. 


\section{INTRODUCTION}

Soil surface roughness is a dynamic property which influences a number of processes at the soil surface controlling runoff and erosion (Zobeck and Onstad, 1987). The most important consequences of a decrease in soil surface roughness are: (i) an increase in the velocity and hence in the erosive power of overland flow; (ii) a decrease of flow depth; and (iii) a decrease of depressional storage of rainfall excess (Onstad, 1984; Huang and Bradford, 1990; Thornes et al., 1990). Depressional storage not only influences infiltration rates, but also protects the depressions from raindrop impact and traps sediment (Onstad, 1984). It is therefore not surprising to find a roughness term in deterministic soil erosion models such as WEPP (Alberts et al., 1989), EUROSEM (Morgan et al., 1993) and MEDALUS (Kirkby et al., 1994).

In general, roughness increases due to soil tillage and decreases during rainfall (Onstad et al., 1984; Govers and Poesen, 1986; Potter, 1990). The smoothening of the surface is much more rapid for soils with a low initial moisture content than for moist soils (Auerswald, 1993). Eventually the surface can become rougher by incision of rills (Govers and Poesen, 1986; Huang and Bradford, 1992). All these results come from soils without rock fragments, where the breakdown of aggregates and subsequent sealing of the surface are the most important processes affecting soil surface roughness change during rainfall (Zobeck and Onstad, 1987).

A large proportion of the soils in the Mediterranean region contains rock fragments both at the surface and in the soil profile (Poesen and Lavee, 1994). Both in recently cultivated agricultural fields and in abandoned fields (especially in the semi-arid part of the Mediterranean region), rock fragments accumulate at the soil surface owing to selective erosion of fines, and act as natural soil surface stabilizers (Poesen et al., 1994). In contrast to soil aggregates, which break down during rainfall (Onstad et al., 1984), rock fragments remain intact at the soil surface and can even increase surface roughness by pedestalling (Auerswald, 1994). The study of roughness of surfaces containing rock fragments (alluvial beds, glacial tills and Mediterranean hillslopes) was already initiated by Robert (1988), Elliot (1989) and Thornes et al. (1990). However, these authors did not relate roughness to rock fragment cover, size and shape in a systematic way.

The objective of this paper is to investigate the effects of rock fragment properties on interrill soil surface roughness. Therefore, the surface roughness evolution of 13 simulated plough layers (i.e. a layer of $19 \mathrm{~cm}$ of fine earth mixed thoroughly with rock fragments) with different rock fragment content, rock fragment size and initial moisture content was studied during rainfall in the laboratory. In order to evaluate the long-term effects of rainfall and sheet erosion on surface roughness of stony interrils, two abandoned hillslopes in southeastern Spain were investigated. These hillslopes are sparsely vegetated and show a large variation in rock fragment cover, owing to selective erosion of fine particles during the approximately 10 years since the last tillage operation. Relations obtained can be used to improve erosion models on stony hillslopes, since such models use frequency distributions of roughness elements in order to predict surface runoff and erosion (Moore and Clarke, 1981; Kirkby et al., 1994).

\section{METHODS}

\section{Laboratory experiments}

Rainfall was simulated by a downward-oriented, single-nozzle, continuous-spray system described in detail by Poesen et al. (1990). At an average intensity of $71 \mathrm{~mm} \mathrm{~h}^{-1}$, median drop size equalled $2 \cdot 2 \mathrm{~mm}$, and after a fall height of $3.25 \mathrm{~m}$, kinetic energy of the rain reached $15.8 \mathrm{~J} \mathrm{~m}^{-2} \mathrm{~mm}^{-1}$ at the soil surface. Rain intensity was measured before and after each experiment. Total rainfall volume $(192.5 \mathrm{~mm})$ for each experiment consisted of four rainfall events lasting $15 \mathrm{~min}, 30 \mathrm{~min}, 60 \mathrm{~min}$ and $60 \mathrm{~min}$ respectively. Mean intensities were $70 \mathrm{~mm} \mathrm{~h}^{-1}$. These events were separated by no-rain periods of $2 \mathrm{~h}, 24 \mathrm{~h}$ and $2 \mathrm{~h}$, respectively.

The plot box used in these experiments consisted of a test area, $0.94 \mathrm{~m}$ long and $0.60 \mathrm{~m}$ wide, surrounded by a buffer area 0.33 to $0.42 \mathrm{~m}$ wide (Poesen et al., 1990). The latter was treated identically to compensate for splash losses. Drainage through the $0.19 \mathrm{~m}$ thick layer of soil was ensured by installing at the bottom of the plot box a hollow, $1 \mathrm{~cm}$ thick, perforated plate covered by a pre-wetted geotextile (Figure 1). The slope of the soil surface in the box was set to 15 per cent in order to minimize the area where ponding occurred.

For each experiment ( 13 in all, including replicates with rock fragment cover by mass $R_{\mathrm{m}}=0$ per cent and 


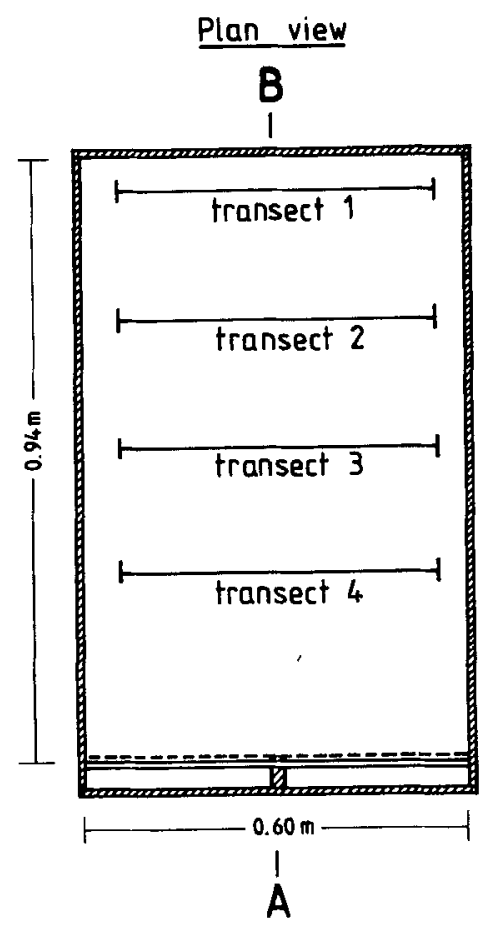

Cross section

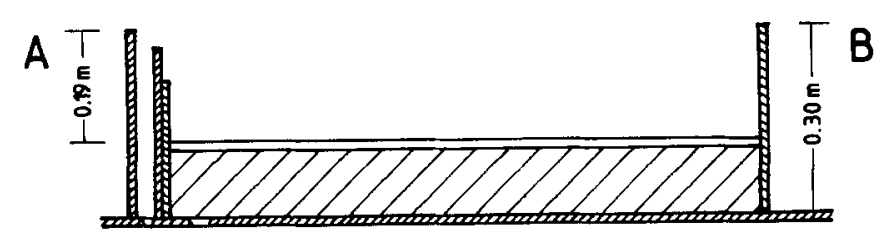

Figure 1. Schematic view of the central test area of the plot box

$R_{\mathrm{m}}=30$ percent), predetermined amounts of fine earth and rock fragments were mixed thoroughly and subsequently transferred to the plot box simulating a plough layer of $19 \mathrm{~cm}$ thickness. The rock fragment contents, rock fragment size and initial moisture content for each experiment are given in Table I. The fine earth consisted of well structured, homogeneous silt loam (17 per cent clay, 81 per cent silt, 2 per cent sand and 1.3 per cent organic matter) sampled in central Belgium. Its dry aggregate distribution was close to that of a fine seedbed: 14 per cent of the aggregates was smaller than $2 \mathrm{~mm}, 46$ per cent was between 2 and $11.2 \mathrm{~mm}, 30$ per cent was between 11.2 and $31.5 \mathrm{~mm}$ and 10 per cent was larger than $31.5 \mathrm{~mm}$. The small rock fragments used in these experiments were well rounded river gravels. The gravels were sieved and only the fraction between 1.7 and $2.7 \mathrm{~cm}$ (round holes) was used. The large rock fragments were sampled in the channel of the Durance river in southern France. The mean diameters of the three axes were: $d_{1}=10.8 \mathrm{~cm}(\mathrm{std}=1.2 \mathrm{~cm}) ; d_{2}=7.7 \mathrm{~cm}(\mathrm{std}=1.3 \mathrm{~cm}) ; d_{3}=4.4 \mathrm{~cm}(\mathrm{std}=1.0 \mathrm{~cm})$. The small rock fragments fall in the medium to coarse gravel size class, whereas the large ones are cobbles (Miller and Guthrie, 1984).

Four fixed transects of $50 \mathrm{~cm}$ length were selected at $20 \mathrm{~cm}$ intervals (see Figure 1) along which the soil surface elevations were determined at $2 \mathrm{~mm}$ intervals using a Selcom laser microreliefmeter driven by a 
Table I. Set-up of the experiments

\begin{tabular}{|c|c|c|c|c|c|c|c|}
\hline \multirow{2}{*}{$\begin{array}{l}\text { Rock fragment } \\
\text { size }\end{array}$} & \multirow{2}{*}{$\begin{array}{l}R_{\mathrm{m}}^{*} \\
(\%)\end{array}$} & \multirow{2}{*}{$\begin{array}{c}\text { Initial } \\
\text { moisture } \\
(\%, w / w)\end{array}$} & \multicolumn{5}{|c|}{ Rock fragment cover (\%) at cumulative precipitation of } \\
\hline & & & 0 & $17 \cdot 5 \mathrm{~mm}$ & $52.5 \mathrm{~mm}$ & $122.5 \mathrm{~mm}$ & $192.5 \mathrm{~mm}$ \\
\hline Control $\dagger$ & 0 & $20 \cdot 0$ & 0 & 0 & 0 & 0 & 0 \\
\hline Control $\dagger$ & 0 & $19 \cdot 4$ & 0 & 0 & 0 & 0 & 0 \\
\hline Control $\uparrow$ & 0 & $18 \cdot 7$ & 0 & 0 & 0 & $\mathbf{0}$ & 0 \\
\hline Small & 31 & 20 & 14 & 19 & 22 & 23 & 23 \\
\hline Small $\dagger$ & 52 & 20 & 35 & 39 & 43 & 43 & 44 \\
\hline Small $\dagger$ & 52 & 19 & 34 & 46 & 51 & 53 & 52 \\
\hline Small & 77 & 21 & 48 & 62 & 62 & 80 & 75 \\
\hline Large & $22 \cdot 6$ & $19 \cdot 7$ & 8 & 10 & 11 & 12 & 12 \\
\hline Large & $51 \cdot 9$ & $19 \cdot 7$ & 13 & 18 & 22 & 25 & 27 \\
\hline Large & $73 \cdot 9$ & $19 \cdot 2$ & 37 & 53 & 63 & 68 & 69 \\
\hline Control & 0 & $3 \cdot 4$ & 0 & 0 & 0 & 0 & 0 \\
\hline Small & $51 \cdot 4$ & $2 \cdot 6$ & 31 & 38 & 46 & 52 & 61 \\
\hline Small & $76 \cdot 9$ & $2 \cdot 6$ & 57 & 69 & 80 & 78 & 86 \\
\hline
\end{tabular}

* Rock fragment content by mass

$\uparrow$ Replicates

computer controlled motor (Römkens et al., 1988; van Wesemael et al., 1994). Scans were made before the experiment and after each rainstorm (Figures 1 and 2).

The rock fragments were painted white, in order to estimate rock fragment cover before and after each rainstorm from orthogonal black and white photos. These were scanned and their rock fragment cover percentage was determined based on contrast differences between the white rock fragments and the dark soil using an image analysis programme.

\section{Field measurements}

Two catenas were selected in the semi-arid part of southeastern Spain (Almeria province). Annual precipitation ranges from $180 \mathrm{~mm} \mathrm{a}^{-1}$ near catena 2 (Cabo de Gata, $50 \mathrm{~m}$ a.s.1.; 1972-1988) to $218 \mathrm{~mm} \mathrm{a}^{-1}$ near catena 1 (Tabernas, $490 \mathrm{~m}$ a.s.1.; 1965-1990). The catenas consist of $600-800 \mathrm{~m}$ long slope sections from crest to pediment. Cultivation of these slopes ceased at least 10 years ago. The sparsely vegetated fields are nowadays grazed by flocks of sheep. The first catena, located near Gergal on the southern fringe of the Sierra de los Filabres, has a northwest exposition, with slope angles varying between 28 and 70 per cent. The parent material is micaschist, which weathers to platy rock fragments at the soil surface. The second catena, located near Cabo de Gata, also has a northwest exposition and slopes vary between 4 and 50 per cent. The parent material is andesite with predominantly cubic, angular rock fragments at the soil surface.

At six and eight sites (representative slope sections) on the two catenas, roughness and total rock fragment cover were determined for six interrill locations (replicates) without vegetation up to $10 \mathrm{~m}$ apart from each other (Figure 3). Soil surface roughness was measured along the contour lines with a contact profile meter along a transect of $50 \mathrm{~cm}$ and a spacing of $2 \mathrm{~mm}$. The surface elevations were copied on a sheet of paper and digitized afterwards. Rock fragment cover was estimated by projecting orthogonal slides of the surface (Figure 3) on a grid ( $2 \mathrm{~cm}$ by $2 \mathrm{~cm}, 10$ by 14 nodes) and counting the number of nodes coinciding with a rock fragment. The size distribution of the rock fragments could be calculated due to the presence of a scale on the slides.

\section{Calculations}

The most frequently used parameter to describe soil surface roughness is the random roughness $(R R)$, which is equal to the standard deviation of de-trended surface elevations (Kuipers,1957; Allmaras et al, 1966: Currence and Lovely, 1970). Originally, the logarithms of the surface elevations were used in order 

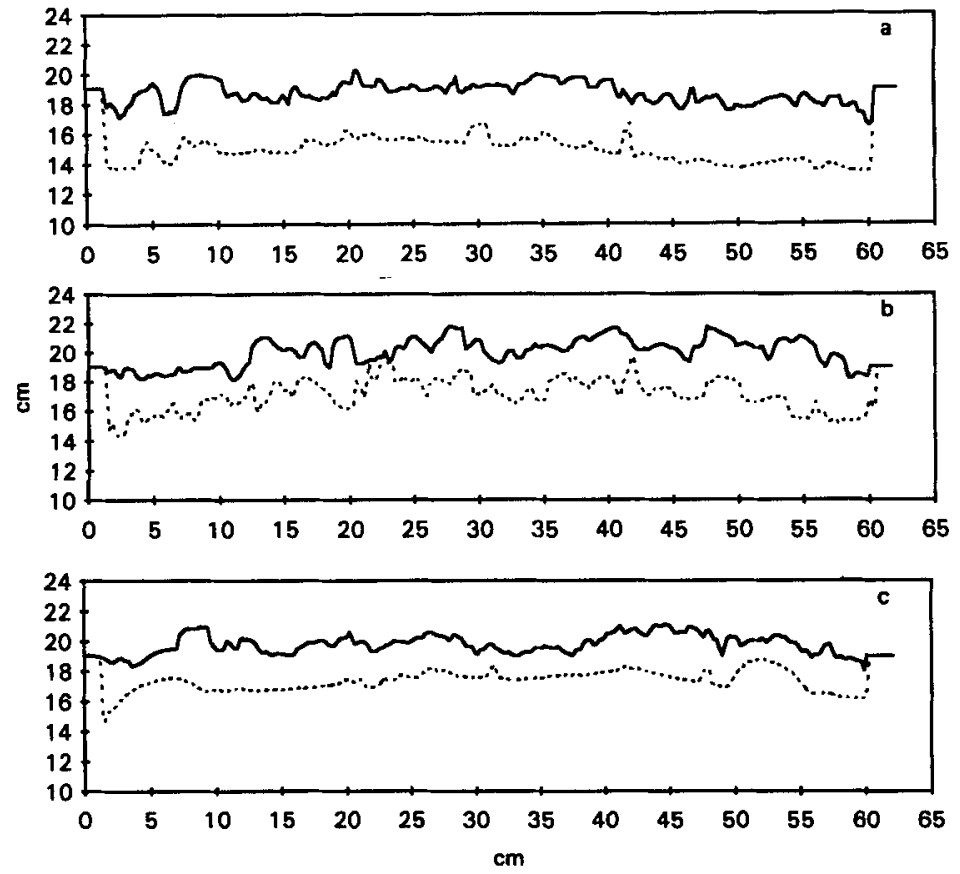

Figure 2. Measured cross-sections before (solid line) and after (dotted line) 192.5 mm rainfall for: (a) moist soil without rock fragments; (b) moist soil with small rock fragments $\left(R_{\mathrm{m}}=52\right.$ per cent); (c) moist soil with large rock fragments $\left(R_{\mathrm{m}}=74\right.$ per cent). $R_{\mathrm{m}}$ is rock fragment content by mass

to obtain a normal distribution, but Currence and Lovely (1970) argued that such a conversion was not required. Recently, the introduction of the laser microreliefmeter (Römkens et al., 1988) permitted a much greater detail in surface elevation measurements. This resulted in the use of spatial roughness indices combining the surface elevations with their spatial pattern (e.g. Linden and van Doren,1986; Römkens and Wang, 1986: Bertuzzi et al., 1990). The disadvantage of these indices is that both spatial pattern and surface elevation interact in a single index (Huang and Bradford, 1992). Therefore, Huang and Bradford (1992) suggested an approach based on modelling semivariograms of surface elevations sampled with a grid size of $0.5 \mathrm{~mm}$. In a Markov-Gaussian model, a correlation length $(L)$, during which semivariance increases with lag, and a sill $\left(\sigma^{2}\right)$, where the semivariance remains constant with lag and is equal to the variance of the entire population, can be distinguished. These two parameters represent the spatial distribution of the surface elevations $(L)$ and the magnitude of the height differences $\left(\sigma^{2}\right)$. One of the major advantages of this approach is that the $\sigma^{2}$ (variance of surface elevations) is directly linked to the classical $R R$ (standard deviation of surface elevations). Huang and Bradford (1990) proved that depressional storage increases both with decreasing $L$ (higher frequency of roughness elements) and with increasing $\sigma^{2}$ (greater variation in surface heights). Their method seems to have some practical drawbacks on slopes, since de-trending of irregular, two-dimensional surfaces is difficult. Therefore, we adapted their methodology, using the mean standard deviation of surface elevations of one-dimensional de-trended transects $(R R)$ in combination with the autocorrelation function rather than the semivariogram. The autocorrelation function is the inverse of the semivariogram for standardized variables (Davis, 1986). As in semivariograms, the correlation length $(L)$ determines the frequency of roughness elements and therefore the roughness at comparable $R R$ (Destain et al., 1989).

The length of the transects (both for field and laboratory experiments) used to calculate the above-mentioned parameters was $50 \mathrm{~cm}$. All transects of surface elevations were first investigated for linear or quadratic (laboratory experiments only) trends. If significant $(P<0.05)$ trends existed, all further calculations were performed with the residuals. The random roughness $(R R$ in $\mathrm{cm})$ in this paper is defined as the mean standard 


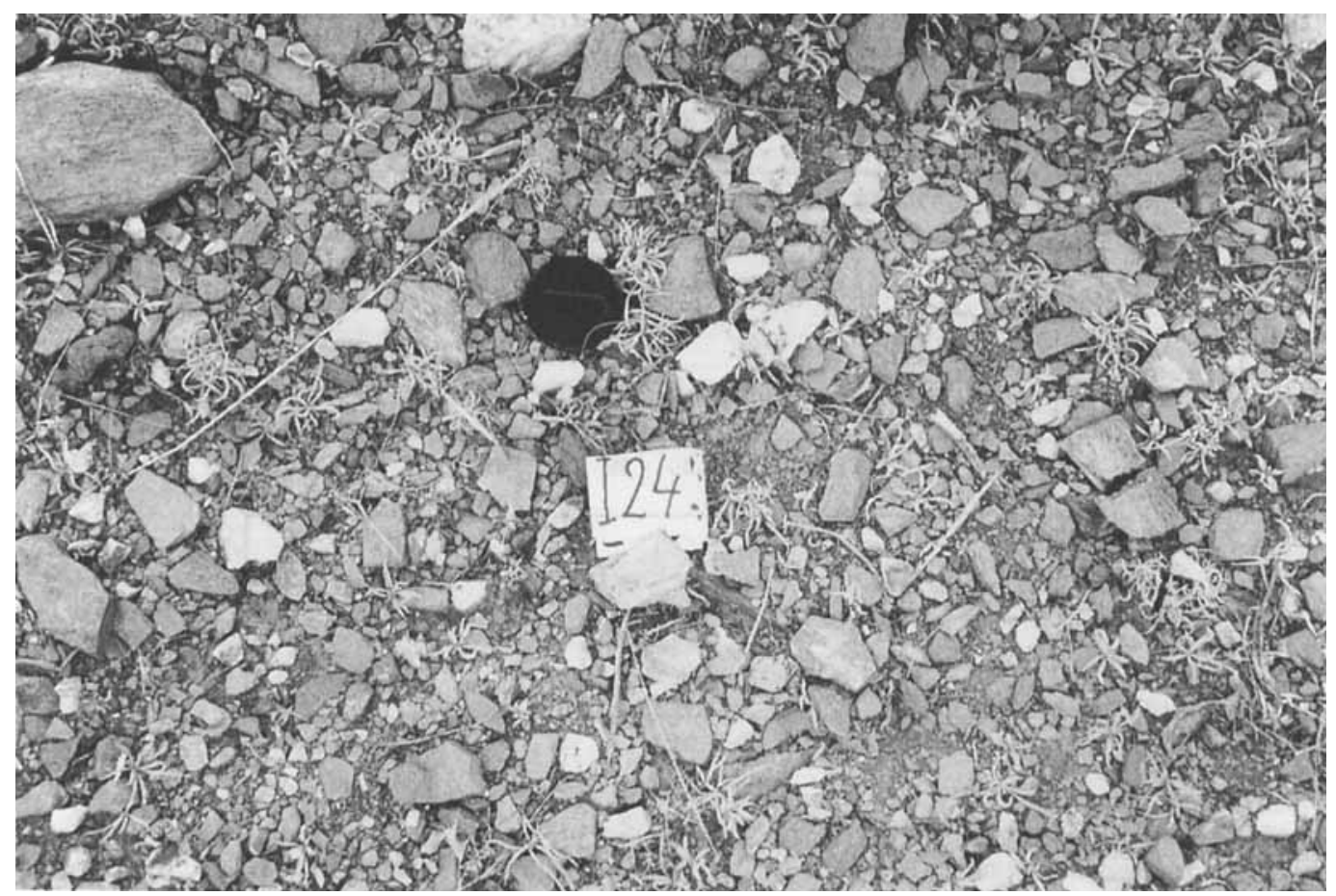

Figure 3. Soil surface of catena 1 near Gergal (southeastern Spain) with platy micaschist rock fragments (cover 59 per cent). Diameter of lens cap is $5 \mathrm{~cm}$

deviation of the surface elevations measured along four transects for laboratory experiments and six transects for field measurements ( 250 elevations per transect). In contrast to the original concept of random roughness (Allmaras et al., 1966), individual transects were used in this paper to calculate $R R$. This approach is necessary especially in the field, in order to avoid biases caused by poor removal of trends on the steep slopes.

The autocorrelation at lag $\tau\left(r_{\tau}\right)$ of the surface elevations $(Y)$ can be calculated from the covariance divided by the variance (Davis, 1986):

$$
r_{\tau}=\frac{\sum Y_{t} Y_{t-\tau}-\sum Y_{t} \sum Y_{t-\tau}}{\sqrt{\left[\sum Y_{t}^{2}-\left(\sum Y_{t}\right)^{2}\right]\left[\sum Y_{t-\tau}^{2}-\left(\sum Y_{t-\tau}\right)^{2}\right]}}
$$

whereby the summations extend from $t=1+\tau$ to $n$. The surface elevations were first linearly interpolated in order to obtain a constant spacing of $2 \mathrm{~mm}$ (SAS Institute, 1985). The autocorrelation function was calculated for lags of $0.8 \mathrm{~cm}$ to a maximum lag of $16 \mathrm{~cm}$. The calculated autocorrelations $\left(r_{\tau}\right)$ of individual transects were modelled by an autocorrelation function of stationary variables (Markov-Gaussian approach; Davis, 1986):

$$
r=\mathrm{e}^{-t / L}
$$

where $r$ is the autocorrelation and $L$ is the correlation length $(\mathrm{cm})$. The correlation length is defined as the maximum distance for which spatial dependence occurs (Davis, 1986). This exponential function was calculated by means of a non-linear fit procedure (SAS Institute, 1985). 


\section{RESULTS AND DISCUSSION}

\section{Evolution of surface roughness during rainfall}

The initial random roughness of the simulated plough layers of all experiments $(R R=0.5-1.2 \mathrm{~cm}$; Figure 4) falls in the range of cultivated soils in seed bed conditions (Currence and Lovely, 1970; Dexter, 1977; Bertuzzi et al., 1990). The random roughness of both initially moist and dry soils without rock fragments shows a decrease with cumulative rainfall (Figure 4). This behaviour can be well described by the relation proposed by Onstad et al. (1984; Equation 3 and Figure 4):

$$
R R=R R_{0}+\beta_{\mathrm{r}}[C R /(1+C R)]
$$

where $R R$ is random roughness $(\mathrm{cm}), R R_{0}$ is initial random roughness $(\mathrm{cm}), C R$ is cumulative rainfall $(\mathrm{cm})$ and $\beta_{\mathrm{r}}$ is a regression coefficient $(\mathrm{cm})$. An exponential fit, as used by Alberts et al. (1989), gave a distinctly lower initial roughness value. The smoothening of the surface is clearly more rapid for initially dry soils than for initially moist soils (c.f. Figures $4 \mathrm{a}$ and $4 \mathrm{c}$ ), which is in agreement with the lower aggregate stability upon wetting of dry soils already reported by, for example, Trumen et al. (1990), Le Bissonais and Singer (1992) and Auerswald (1993).

A completely different behaviour of the soil surface during rainfall is observed for soils containing rock fragments (Figures 2 and 4). For both initially moist and dry soils containing small rock fragments $(1 \cdot 7-$ $2.7 \mathrm{~cm}$ ), $R R$ decreases during the first $17.5 \mathrm{~mm}$, after which it increases with cumulative rainfall. For soils containing large rock fragments $(7.7 \mathrm{~cm}), R R$ increases with cumulative rainfall when $R_{\mathrm{m}}=52$ per cent or more (Figure $4 \mathrm{~b}$ ). The $R R$ of soils containing 74 per cent of large rock fragments by mass is distinctly higher than the $R R$ for other soils throughout the rainfall simulation.

The increase in $R R$ with rainfall can be explained by two mechanisms which are simultaneously active: breakdown of aggregates, and washing of fine particles in the depressions between the rock fragments. During the initial stage (up to $17.5 \mathrm{~mm}$ of rainfall), soil aggregates are still abundant. In this stage, roughness is determined by tillage practices (Zobeck and Onstad, 1987). Thereafter, soil aggregates are mostly destroyed, and roughness is determined by protruding rock fragments (Figure 2). According to Auerswald (1994), rock fragments create elevations on the levelled soil surface. On the one hand, these rock fragments are pedestalled by destruction of surrounding soil aggregates and selective erosion of fine earth, while on the other hand rock fragments from the subsurface emerge and rock fragment cover increases (Table I). This process is similar to the formation of an erosion pavement (Thornes et al., 1990). It should be noted that increase of roughness by the formation of rills, as observed by Huang and Bradford (1992) was not observed during these experiments owing to the limited size of the interrill plot box.

\section{Roughness of degraded laboratory soils}

The soil surface exposed to $192.5 \mathrm{~mm}$ of rainfall in the laboratory were investigated for both their random roughness and the spatial pattern of the roughness elements (Figures $5 \mathrm{a}$ and $5 \mathrm{~b}$ ). For soils containing small rock fragments, $R R$ increases with rock fragment cover to reach its maximum at 50-60 per cent rock fragment cover. For soils containing large rock fragments, $R R$ increases non-linearly up to a cover of about 70 per cent. At low and intermediate rock fragment covers, the range in $R R$ does not vary much between soils containing small rock fragments and those containing large rock fragments, while at high rock fragment surface covers, the soils with large rock fragments show a much higher $R R$ (Figure 5a). At low and intermediate rock fragment contents, the large rock fragments are partly embedded in fine earth which diminishes their effective height, while at high rock fragment contents, rock fragments rest on each other and there is not enough fine earth to fill the depressions between the rock fragments.

The correlation length of soils containing large rock fragments is comparable to that of bare soils and shows no variation with rock fragment content. For soils containing small rock fragments, $L$ decreases with increasing rock fragment content (Figure 5b). The measured values of $L$ are distinctly lower than those given by Robert (1988).

The implications of spatial dependence in roughness elements for depressional storage were shown by Huang and Bradford (1990). They calculated that for a slope of 10 per cent and a $R R$ of $1 \mathrm{~cm}$, depressional 

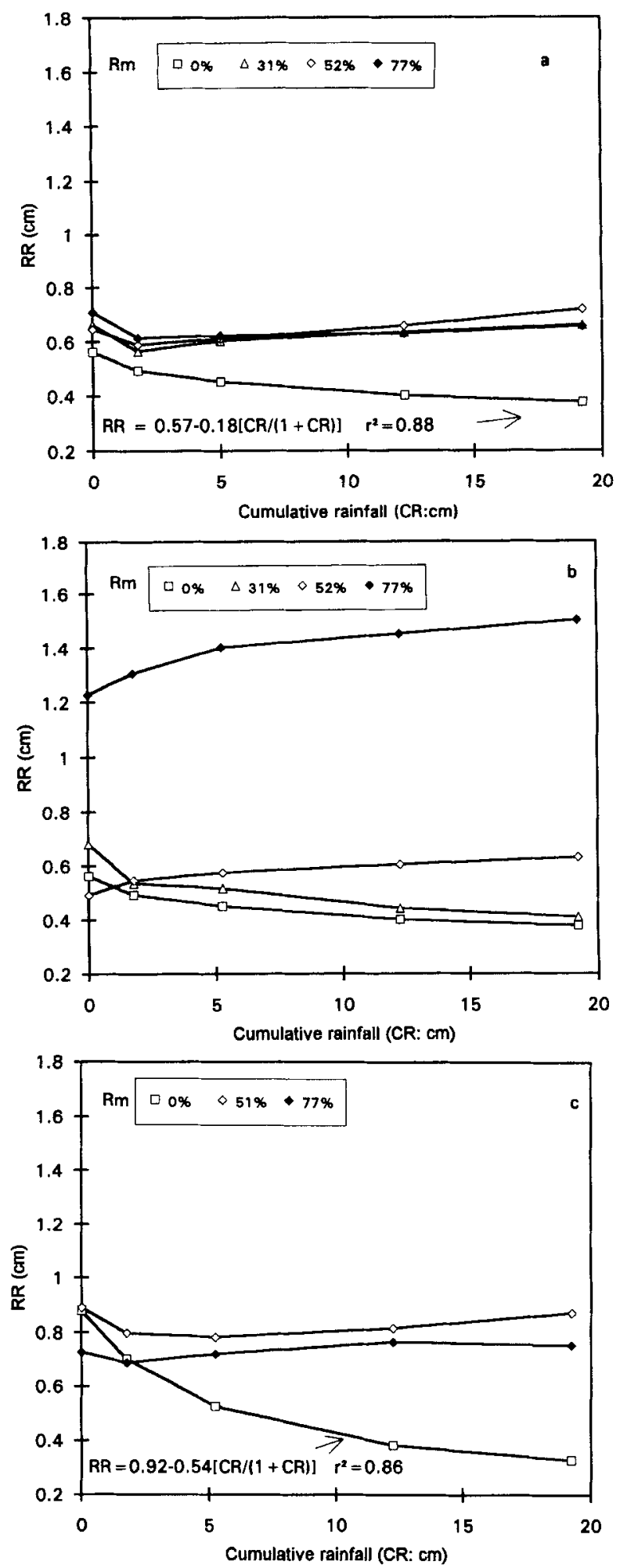

Figure 4. Evolution of random roughness $(R R)$ during rainfall for: (a) small rock fragments $(1.7-2.7 \mathrm{~cm})$ in a moist soil $\left(0.20 \mathrm{~kg} \mathrm{~kg}^{-1}\right)$; (b) large rock fragments $(7.7 \mathrm{~cm})$ in a moist soil $\left(0.20 \mathrm{~kg} \mathrm{~kg}^{-1}\right)$; (c) small rock fragments $(1.7-2.7 \mathrm{~cm})$ in a dry soil $\left(0.03 \mathrm{~kg} \mathrm{~kg}^{-1}\right) . R_{\mathrm{m}}$ is rock fragment content by mass 

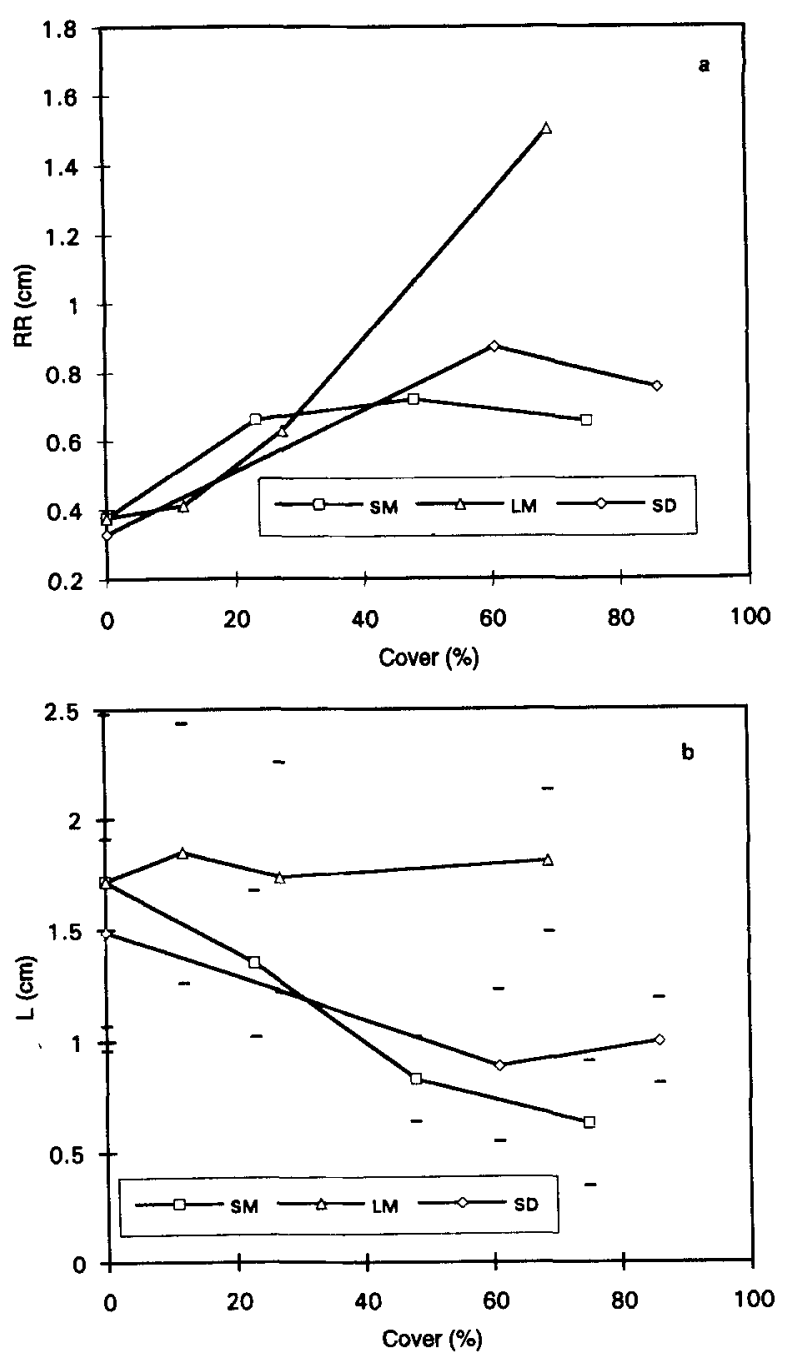

Figure 5. Relation between surface rock fragment cover (cover) and roughness: (a) random roughness ( $R R$ ); (b) correlation length $(L)$. All plots represent the situation after $192.5 \mathrm{~mm}$ rainfall for small rock fragments $(\mathrm{SM}, 1.7-2.7 \mathrm{~cm})$ in a moist soil $\left(0.20 \mathrm{~kg} \mathrm{~kg}{ }^{-1}\right)$; large rock fragments $(\mathrm{LM}, 7.7 \mathrm{~cm})$ in a moist soil $\left(0.20 \mathrm{~kg} \mathrm{~kg}^{-1}\right)$; small rock fragments $(\mathrm{SD}, 1.7-2.7 \mathrm{~cm})$ in a dry soil $\left(0.03 \mathrm{~kg} \mathrm{~kg}^{-1}\right)$

storage increased from $1.4 \mathrm{~mm}$ for surfaces with $L=2 \mathrm{~cm}$ to $1.6 \mathrm{~mm}$ for surfaces with $L=1 \mathrm{~cm}$. In our situation, this would imply that below 40 per cent rock fragment cover (where $R R$ is comparable for soils with small and large rock fragments), depressional storage would be larger for soils containing small rock fragments than for those with large rock fragments (Figures $5 \mathrm{a}$ and $5 \mathrm{~b}$ ). In these conditions, it can be seen from the transects in Figure 2 that with a rock fragment cover of, for example, 40 per cent the rock fragments will protrude from the surface. This implies that the remaining bare soil between will be protected against raindrop impact by a water film of $c .2 .3$ or $2.7 \mathrm{~mm}$ thickness, respectively, for soils with large and small rock fragments.

\section{Roughness of soil surfaces along catenas in semi-arid Spain}

Despite the large variations between individual sites, rock fragment cover increases non-linearly with slope along two catenas in southeastern Spain (Figure 6). Recently, Poesen and Bunte (1994) and Simanton et al. 

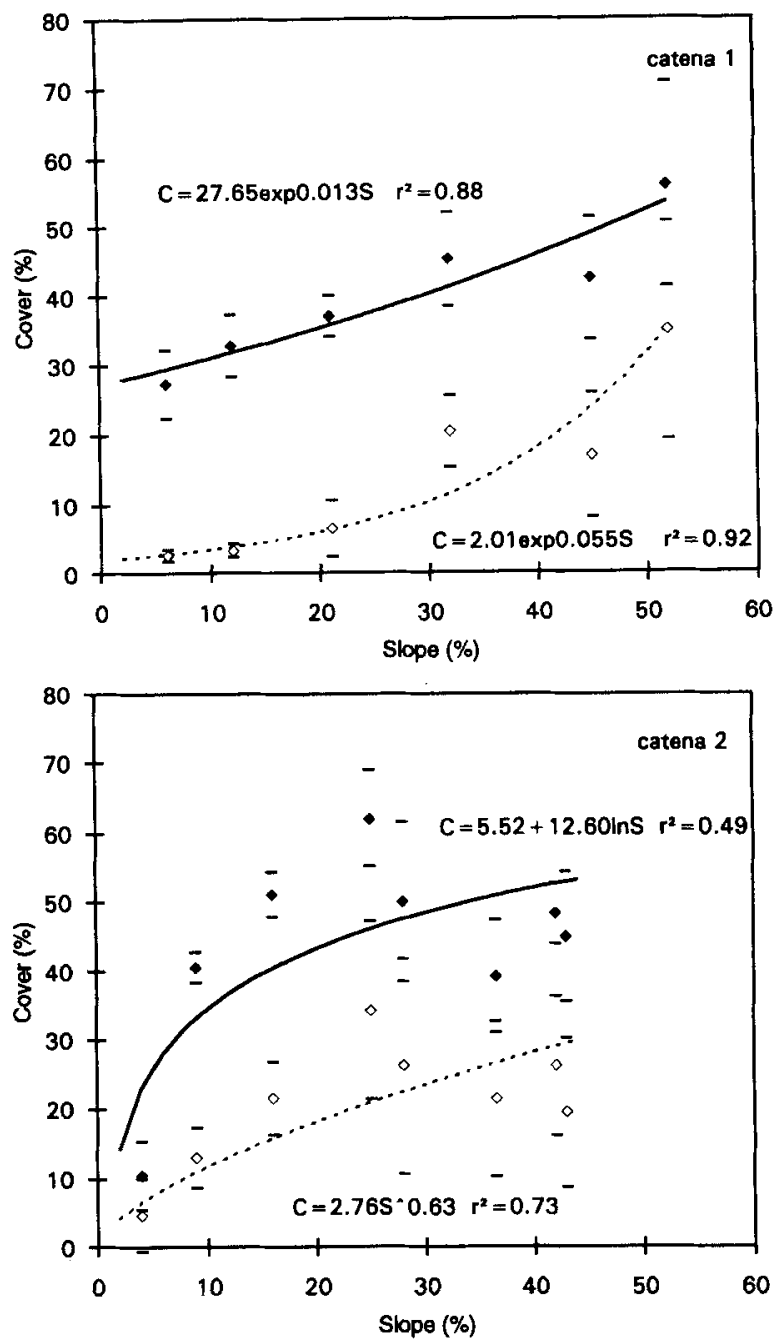

Figure 6. Rock fragment cover, including standard deviation ( $>5 \mathrm{~mm}$ closed symbols; $>25 \mathrm{~mm}$ open symbols), versus slope angle on two catenas in southeastern Spain. Catena 1 is covered with platy micaschist and catena 2 with cubic andesites

(1994) argued that on semi-arid hillslopes, rock fragment cover increases logarithmically with slope angle owing to selective erosions of fine particles on steep slope segments. The soil surface of the investigated hillslopes was not ploughed for at least 10 years and can thus be considered to be the result of long-time degradation by raindrop impact and selective interrill erosion. Random roughness also increases non-linearly with slope (Figure 7). These relationships are similar to those describing the increase of cover by medium to large rock fragments $(>25 \mathrm{~mm}$ ) with slope: an exponential increase for the catena covered with micaschists and a degressive increase for the hillslope covered with andesites (Figure 6). The similarity between the increase of rock fragment cover and $R R$ with slope agrees well with the results of the laboratory experiments, which show an increase of $R R$ with rock fragment cover for degraded soil surfaces. The shape of the rock fragments seems also to be important. Since platy micashists weather more easily to small-sized fragments than the cubic andesites, the increase in cover and in $R R$ with slope is strongest (Figures 6 and 7).

Because of the simultaneous variation in rock fragment cover and rock fragment size with slope, correlation lengths $(L)$ do not show any clear relationships with slope (Table II). This may again be explained using 
the results of the laboratory experiments. These indicate that $L$ generally decreases with increasing rock fragment cover, but also that $L$ increases with increasing rock fragment size. As both factors increase with slope, their effects may out-balance each other. Differences in correlation length between the two rock fragment types cannot be found either. The range of the correlation length measured along the two catenas ( $L=1.84-3.41 \mathrm{~cm}$; Table II) for low rock fragment covers is clearly higher than that found in the laboratory experiments $(L=0.63-1.85 \mathrm{~cm}$; Figure $5 \mathrm{~b})$. There are various possible explanations for the smaller frequency of roughness elements (larger $L$ ) on hillslopes, which received approximately $2000 \mathrm{~mm}$ in the past 10 years after their abandonment, when compared to simulated plough layers: these include the heterogeneity of the rock fragment sizes, differential compaction of the soil surface, and development of microrills. Considering the comparable range of $R R$ between simulated plough layers and abandoned hill slopes (Figures 5a and 7 ) and the larger $L$ for the latter soils, one can expect that depressional storage and the depth of the protecting water film are smaller on abandoned soils than on recently cultivated ones (Huang and Bradford, 1990).

The above-mentioned relationships for two semi-arid hillslopes allow one to estimate roughness of interrill areas with its related parameters (depressional storage and percentage surface exposed to direct raindrop impact) from slope angles and lithology, which can be obtained from a digital terrain model and a geological map. A more accurate prediction of roughness along hillslopes will improve results obtained from erosion models (Moore and Clarke, 1981; Kirkby et al., 1994) which are used in areas with soils containing rock fragments.

\section{CONCLUSIONS}

For practical purposes, both variation in height of roughness elements (random roughness: $R R$ ) and their spatial characteristics (correlation length: $L$ ) are required to describe soil surface roughness. The frequently used assumption that roughness of cultivated topsoils decreases exponentially with cumulative rainfall is not valid for soils containing rock fragments. Decrease of $R R$ only occurs in the initial stage, when soil aggregates break down. Afterwards, rock fragments protrude from the surface and may increase surface roughness. The difference in $R R$ between small and large rock fragments is most clear when rock fragment contents

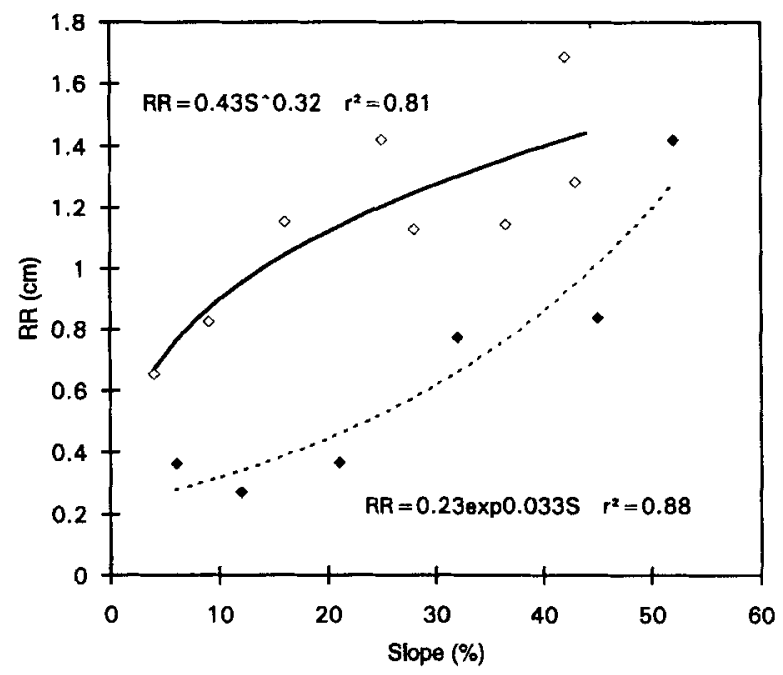

Figure 7. Relations between slope angle and random roughness $(R R)$ along two catenas located on different lithology in southeastern Spain: micaschists (catena 1; closed symbols) and andesites (catena 2; open symbols) 
Table II. Slope angle, random roughness $(R R)$ and correlation length $(L)$ along two catenas in southeastern Spain

\begin{tabular}{|c|c|c|c|c|c|}
\hline \multirow[b]{2}{*}{ Site } & \multirow{2}{*}{$\begin{array}{c}\text { Slope } \\
(\%)\end{array}$} & \multicolumn{2}{|c|}{$R R(\mathrm{~cm})$} & \multicolumn{2}{|c|}{$L(\mathrm{~cm})$} \\
\hline & & mean & std & mean & std \\
\hline \multicolumn{6}{|c|}{ Catena 1 (micaschist) } \\
\hline 1 & 6 & 0.36 & 0.22 & $2 \cdot 61$ & $1 \cdot 16$ \\
\hline 2 & 12 & $0 \cdot 27$ & 0.09 & $2 \cdot 24$ & 0.39 \\
\hline 3 & 21 & 0.37 & $0 \cdot 12$ & $2 \cdot 49$ & 1.03 \\
\hline 4 & 32 & 0.78 & 0.28 & $2 \cdot 73$ & $1 \cdot 70$ \\
\hline 5 & 45 & 0.84 & 0.41 & $2 \cdot 31$ & 0.62 \\
\hline 6 & 52 & $1 \cdot 42$ & 0.75 & $2 \cdot 98$ & $1 \cdot 26$ \\
\hline \multicolumn{6}{|c|}{ Catena 2 (andesite) } \\
\hline 1 & 4 & 0.66 & 0.39 & $3 \cdot 27$ & 1.25 \\
\hline 2 & 9 & 0.83 & 0.41 & $2 \cdot 81$ & 0.39 \\
\hline 3 & 16 & 1.42 & 0.30 & $2 \cdot 94$ & 0.88 \\
\hline 4 & 25 & $1 \cdot 15$ & 0.80 & 1.84 & 0.72 \\
\hline 5 & 28 & $1 \cdot 13$ & 0.67 & $2 \cdot 34$ & 1.09 \\
\hline 6 & 37 & $1 \cdot 14$ & 0.52 & $2 \cdot 13$ & 0.87 \\
\hline 7 & 42 & 1.69 & 0.58 & $3 \cdot 41$ & 1.01 \\
\hline 8 & 43 & 1.29 & 0.39 & $2 \cdot 77$ & $1 \cdot 15$ \\
\hline
\end{tabular}

by mass are larger than 50 per cent, and there is not enough fine earth to partly embed the large rock fragments. The frequency of roughness elements of soils containing small rock fragments increases with rock fragment content and is distinctly larger (smaller $L$ ) than the frequency of roughness elements of soils containing large rock fragments. The latter remains constant at the level of soils free of rock fragments. Owing to the increased depressional storage (large $R R$ and small $L$ ) of soils containing small rock fragments, the fine earth between the rock fragments is protected from raindrop impact. The simultaneous, non-linear increase of rock fragment cover and random roughness of interrill areas with slope angle along two degraded semiarid hillslopes agrees well with the results of the laboratory experiments: roughness of stony soils is mainly determined by rock fragment content and size. The correlation length of the surfaces along these hillslopes did not show a relationship with slope, probably because of the simultaneous increase in rock fragment cover and size. The clear relation between rock fragment cover, random roughness and slope on semi-arid hillslopes offers an opportunity to improve erosion models for stony soils.

\section{ACKNOWLEDGEMENTS}

The authors wish to thank Dr J. Puigdefabregas and Dr A. Solé for providing background information on the field sites. The research for this paper was carried out as part of the MEDALUS II (Mediterranean Desertification and Land Use) collaborative research project. MEDALUS II was funded by the European Union under its Environment Programme, contract number EV5V0128, and the support is gratefully acknowledged. Participation of T.D.F. in the experiments was financially supported by the PortugalBelgium Scientific and Cultural Agreement. We therefore thank the Instituto Nacional de Investigacão Cientifica (Portugal), the Ministry of the Flemish Community (Belgium) and the Escola Superior Agrária, Instituto Politécnico de Bragança (Portugal).

\section{REFERENCES}

Alberts, E. E., Laflen, J. M., Rawls, W. J., Simanton, J. R. and Nearing, M. A. 1989. 'Soil Component', in Lane, L. J. and Nearing, M. A. (Eds), Water Erosion Prediction Project; Hillslope profile documentation, NSERL Report 2, W. Lafayette, Indiana, 6.1-6.15. Allmaras, R. R., Burwell, R. E., Larson, W. E. and Holt, R. F. 1966. Total Porosity and Random Roughness of the Interrow Zone as Influenced by Tillage, USDA Conservation Research Report 7. 
Auerswald, K. 1993. 'Influence of initial moisture and time since tillage on surface structure breakdown and erosion of a loessial soil', Catena Supplement, 24, 93-101.

Auerswald, K. 1994. 'Changes in soil surface roughness during erosive rains', in Morgan, R. P. C. and Quinton, J. N. (Eds), The European Soil Erosion Model, (in prep.).

Bertuzzi, P., Rauws, G. and Courault, D. 1990. 'Testing roughness indices to estimate soil surface roughness changes due to simulated rainfall', Soil and Tillage Resarch, 17, 87-99.

Currence, H. D. and Lovely, W. G. 1970. 'The analysis of soil surface roughness', Transactions American Society of Agricultural Engineers, 13, 710-714.

Davis, J. C. 1986. Statistics and Data Analysis in Geology, 2nd edn, John Wiley, New York.

Destain, M. F., Descornet, G., Roisin, C. and Frankinet, M. 1989. 'Investigation of soil degradation by means of opto-electric microreliefmeter', Soil and Tillage Research, 13, 299-315.

Dexter, A. R. 1977. 'Effect of rainfall on the surface micro-relief of tilled soil', Journal of Terramechanics, 14, 11-22.

Elliot, J. K. 1989. 'An investigation of the change in surface roughness through time on the foreland of Austre Okstindbreen, North Norway', Computers and Geosciences, 15, 209-217.

Govers, G. and Poesen, J. 1986. 'A field-scale study of surface sealing and compaction on loam and sandy loam soils. Part I: Spatial variability of soil surface sealing and crusting', in Callebaut, F., Gabriëls, D. and De Boodt, M. (Eds), Assessment of Soil Surface Sealing and Crusting, University of Gent, Belgium, 171-182.

Huang, C. H. and Bradford, J. M. 1990. 'Depressional storage for Markov-Gaussian surfaces', Water Resources Research, 26, 22352242.

Huang, C. H. and Bradford, J. M. 1992. 'Applications of a laser scanner to quantify soil microtopography', Soil Science Society of America Journal,56, 147-221.

Kirkby, M. J., Baird, A. J., Lockwood, J. G., McMahon, M. D., Mitchell, P. M., Shao, J., Sheehy, J. E., Thornes, J. B. and Woodward, F. J. 1994. 'The MEDALUS hillslope model', in Thornes, J. B. and Brandt, J. (Eds), Mediterranean Desertification and Lane Use, J. Wiley and Sons, Chichester (in press).

Kuipers, H. 1957. 'A relief meter for soil cultivation studies', Netherlands Journal of Agricultural Science, 5, 255-262.

Le Bissonais, Y. and Singer, M. J. 1992. 'Crusting, runoff and erosion response to soil water content and successive rainfalls', Soil Science Society of America Journal, 56, 1898-1903.

Linden, D. R. and van Doren, D. M. 1986. 'Parameters for characterizing tillage-induced soil surface roughness', Soil Science Society of America Journal, 50, 1550-1565.

Miller, F. and Guthrie, R. 1984. 'Classification and distribution of soils containing rock fragments in the United States' in Nichols, J. D., Brown, P. L. and Grant, W. J. (Eds), Erosion and Productivity of Soils Containing Rock Fragments, Soil Science Society of America, Special Publication 13, Madison, WI, 1-12.

Moore, R. J. and Clarke, R. T. 1981. 'A distribution function approach to runoff modelling', Water Resources Research, 17, $1367-1383$.

Morgan, R. P. C., Quinton, J. N. and Rickson, R. J. 1993. EUROSEM: A User Guide, Silsoe College, United Kingdom.

Onstad, C. A. 1984. 'Depressional storage on tilled soil surfaces', Transactions American Society of Agricultural Engineers, $27,729-732$.

Onstad, C. A., Wolf, M. L., Larson, C. L. and Slack, D. C. 1984. 'Tilled soil subsidence during repeated wetting', Transactions American Society of Agricultural Engineers, 27, 733-736.

Poesen, J. and Bunte, K. 1994. 'Effects of rock fragments on desertificaton processes in Mediterranean environments', in Thornes, J. and Brandt, J. (Eds), Mediterranean Desertification and Land Use, J. Wiley and Sons, Chichester (in press).

Poesen, J. and Lavee, H. 1994. 'Rock fragments in top soils: Significance and processes', Catena, 23, 1-28.

Poesen, J. Ingelmo-Sanchez, F. and Mücher, H. 1990. 'The hydrological response of soil surfaces to rainfall as affected by cover and position of rock fragments in the top layer', Earth Surface Processes and Landforms, 15, 653-671.

Poesen, J., Torri, D. and Bunte, K. 1994. 'Effects of rock fragments on soil eroson by water at different spatial scales: a review', Catena, 23, 141-166.

Potter, K. N. 1990. 'Soil properties effect on random roughness decay by rainfall', Transactions American Society of Agricultural Engineers, 33, 1889-1892.

Robert, A. 1988. 'Statistical properties of sediment bed profiles in alluvial channels', Mathematical Geology, 20, $205-225$.

Römkens, M. J. M. and Wang, J. Y. 1986. 'Effect of tillage on surface roughness', Transactions American Society of Agricultural Engineers, 29, 429-433.

Römkens, M. J. M., Wang, J. Y. and Darden, R. W. 1988. 'A laser microreliefmeter', Transactions American Society of Agricultural Engineers, 31, 408-413.

SAS Institute Inc. 1985. SAS User's Guide: Statistics, Version 5, Cary, NC, USA.

Simanton, J. R., Renard, K. G., Christiaensen, C. M. and Lane, L. J. 1994. 'Spatial distribution of surface rock fragments along catenas in semi-arid Arizona and Nevada, USA', Catena, 23, 29-42.

Thornes, J. B., Francis, C. F., Lopez Bermudez, F. and Romero Diaz, A. 1990. 'Reticular overland flow with coarse particles and vegetation roughness under Mediterranean conditions', in Rubio, J. L. and Rickson, R. J. (Eds), Strategies to combat desertification in Mediterranean Europe, Commission of the EUR 11175, 228-243.

Truman, C. C., Bradford, J. M. and Ferris, J. E. 1990. 'Antecedent water content and rainfall energy influence on soil aggregate break down', Soil Science Society of America Journal, 54, 1385-1392.

van Wesemael, B., Poesen, J. and de Figueiredo, T. 1994. 'Effects of rock fragments on physical degradation of cultivated soils by rainfall', Soil and Tillage Research 33, 229-250.

Zobeck, T. M. and Onstad, C. A. 1987. 'Tillage and rainfall effects on random roughness: a review', Soil and Tillage Research,9, 1-20. 